\title{
Influence of Different Wrapping Materials on Microbiological, Physicochemical and Sensory Properties of Condiment Product 'Ogiri-egusi'
}

\author{
Francis Sopuruchukwu Ire ${ }^{1, *}$, Ogechi Mishelle Eze ${ }^{2}$, Ndukwe Maduka ${ }^{3}$ \\ ${ }^{1}$ Department of Microbiology, Faculty of Science, University of Port Harcourt, Nigeria (francis.ire@ uniport.edu.ng) \\ ${ }^{2}$ Department of Microbiology Technology, Faculty of Science Laboratory Technology, University of Port Harcourt, Nigeria \\ (ezemishelle@gmail.com) \\ ${ }^{3}$ Department of Biological Sciences, Faculty of Natural and Applied Science, Wellspring University, Benin City, Edo State, \\ Nigeria (maduks.mn@gmail.com) \\ *Correspondence: francis.ire@uniport.edu.ng
}

\begin{abstract}
Ogiri' is a locally fermented product from oil seeds such as melon seeds (Citrullus vulgaris). It is commonly used as condiments to enhance the flavour of the variety of foods. This study was aimed at determining the influence of different wrapping materials on microbial load, proximate composition, physicochemical and sensory properties of indigenous fermented melon seeds known as "ogiriegusi". Melon seeds obtained from the local market were dehulled, wrapped in banana leaf, boiled and mashed. The mashed 'ogiri egusi' was separately wrapped using aluminium foil, paper, banana leaf, transparent and black cellophane and allowed to ferment for five (5) days. Daily pH monitoring of the samples was carried out while microbiological analysis and proximate composition of the fermented products were determined using Standard Methods while Sensory evaluation was carried out using a 9-point Hedonic scale. The sample wrapped with banana leaf had the highest total heterotrophic bacterial count (THC) of 6.08 log10 CFU/g), total coliform count (CC) of $4.88 \log 10 \mathrm{CFU} / \mathrm{g}$, total Staphylococcal count (TSC) of $5.07 \log 10 \mathrm{CFU} / \mathrm{g}$ ) and total fungal count (TFC) of $3.75 \mathrm{log} 10$ CFU/g). On the contrary, ogiri-egusi wrapped with aluminum foil had the lowest THC (5.84 $\log 10 \mathrm{CFU} / \mathrm{g})$, TCC (4.39 log10 CFU/g), TSC (4.83 $\log 10$ CFU/g), TLC (3.61 $\log 10$ CFU/g) and TFC (3.39 $\log 10$ CFU/g). Staphylococcus sp., Micrococcus sp., Bacillus sp. and Lactobacillus sp., Aspergillus niger, A. flavus, Fusarium sp., Saccharomyces sp., Penicillium sp. and Candida sp. were isolated from the samples wrapped with different materials. There was a slight increase in $\mathbf{p H}$ with an increase in fermentation time in all samples irrespective of the wrapping material. There were significant differences $(P<0.005)$ in proximate composition and sensory scores of the samples wrapped with different materials. Ogiri-egusi wrapped with aluminium foil was most preferred based on sensory scores. Considering the results obtained from the microbial analysis, proximate composition and sensory properties of ogiri-egusi wrapped with different materials, aluminium foil is recommended as a wrapping material. This will enhance the microbial and aesthetic qualities of this locally fermented condiment product for improved utilization.
\end{abstract}

Keywords: Melon seeds, Wrapping materials, Microbial quality, Sensory and Physicochemical properties.

Received: July $10^{\text {th }}, 2020 /$ Accepted: August $20^{\text {th }}, 2020 /$ Online: September $15^{\text {th }}, 2020$

\section{INTRODUCTION}

Fermentation involves the use of microorganisms and their enzymes during the processing of different foods and food products to achieve desirable characteristics. It is regarded as being one of the oldest technologies involved in the production of various food products (Olanbiwoninu and Odunfa, 2018). The process enhances flavour, improves palatability, protein value, mineral and vitamin content of foods as well as promote food preservation and food safety. Food fermentation also lowers anti-nutritional factors, improves the functional properties of certain foods and result in varieties of diets (Achi and Okereka, 1999; Akinyele and Oloruntoba, 2013). Indigenous fermented food condiments in Africa are diverse depending on raw materials, country and region where they are produced (Chukwu et al., 2019; Olasupo and Okorie, 2019). A typical example is 'ogiri' which is an oily paste prepared using oil seeds common in West Africa such as melon seeds (Citrullus vulgaris), fluted pumpkin (Telferia occidentallis), African oil bean seed (Pentaclethra macrophylla) and castor oil seeds (Ricimus 
communis). The Igbos use the name 'ogiri' to identify condiments fermented traditionally using vegetable proteins. 'Ogiri-egusi', 'ogiri-ugu', 'ogiri-isi', 'ogiri-ugba' and 'okpiye' are varieties of ogiri prepared using different raw materials depending on the people and their locality. These fermented products are utilized largely by those living in rural communities to add flavour to soup and stew as well as other traditional dishes. In this study, melon seeds (Citrullus vulgaris) was selected among oil seeds for the production of a condiment product 'ogiri egusi' due to its popularity as a thickener for preparing diverse local soups in Nigeria. Also, melon is widely cultivated in the country with an estimated output of 347,000 tonnes in 2002 (Peter-Ikechukwu et al., 2016). Presently, the output must have increased tremendously due to government and private sector intervention to improve agricultural practices in Nigeria in the last two decades. Naturally, ogiri-egusi has a very strong pungent odour. A strong aromatic smell is released when ogiri-egusi is dropped inside soup pot (Azi et al., 2017; Chukwu et al., 2018; Ogbuonye, 2018). Incorporating 'ogiri' into diets provides additional protein, minerals and calories. Consumption of such foods offers some health benefits to the body (Ibeabuchi et al., 2014; Egbebi et al., 2016). According to Chukwu et al. (2018), health benefits of fermented condiments include reduction of high cholesterol levels in the blood as well as the ability to fight and prevent tuberculosis, cancer and cardiovascular complications by boosting body immune system.

Locally, the process of preparing ogiri involves boiling of the seeds, cooling, wrapping in leaves and allowing it to ferment at ambient temperature and humidity for 3-5 days. Ogiri is commonly packaged using leaves and earthen wares. Sometimes, cement papers are used to cover the product (Peter-Ikechukwu et al., 2015). Leaves used in wrapping ready-to-eat food products infuse beneficial phytonutrients as well as gives the product unique taste, aroma and natural flavour (Kabuo et al., 2015; PeterIkechukwu et al., 2016). The number of leaves and layers used in wrapping mashed melon seeds used to prepare ogiriegusi varies among individuals (Ogueke et al., 2013). The use of leaves to wrap ogiri predisposes the product to crosscontamination by undesirable microorganisms and short shelf life (Adegunloye et al., 2006; Kabuo et al., 2015). Various workers have reported different microorganisms involved in fermenting melon seeds of which Bacillus subtilis has been identified as the key bacterium (Barber $e t$ al., 1988; Barimalaa et al., 1989; Barber and Achinewhu, 1992; Sanni et al., 2000; Olasupo and Okorie, 2019).

Notwithstanding the offensive aroma of ogiri, poor aesthetic appeal, short shelf life and risk of contamination by undesirable microorganisms remains a limitation to its wide acceptability. The use of modern packaging materials such as polypropylene, polystyrene, aluminium foil etc promises to overcome some of these limitations (Kabuo et al., 2015). The essence of food packaging is to preserve and protect all types of food materials from light, moisture re-absorption, rodents, microbial spoilage and oxidation among others.
Peter-Ikechukwu et al. (2015) investigated the effect of wrapping materials such as unblanched leaves, blanched leaves, dried leaves, aluminium foil, transparent polyethylene and black polyethylene on chemical and microbiological qualities of fermented melon seed (ogiriegusi). Findings from their study revealed that black polyethylene bag followed by aluminium foil were the most preferred wrapping material. Since there are diverse wrapping materials and assorted food products, limited studies have so far been carried out on the effect of some wrapping materials on some locally fermented condiments such as ogiri-egusi. Therefore, this study was aimed at determining the effect of different packaging materials on microbial load, proximate composition, physicochemical properties and sensory properties of ogiri-egusi.

\section{MATERIALS AND METHODS}

\section{A. Sample collection}

Melon seeds (Citrullus vulgaris) and wrapping materials (aluminum foil, paper, transparent and black cellophanes) were purchased from a local seller at Rumuokoro market in Port Harcourt, Rivers State, Nigeria. Dried banana leaves were collected from a farm and identified in the herbarium of the Department of Plant Science and Biotechnology, University of Port Harcourt. All the materials were taken to Microbiology Laboratory, the University of Port Harcourt under aseptic condition for analysis.

\section{B. Production of ogiri-egusi (Fermented Citrullus vulgaris Seeds)}

The procedure described by Kabuo et al. (2015) with slight modification was adopted in the preparation of ogiri-egusi. Five hundred grams $(500 \mathrm{~g})$ of undehulled melon seeds were washed with potable water and then boiled for $3 \mathrm{~h}$ before allowing it to cool to room temperature $\left(28 \pm 2{ }^{\circ} \mathrm{C}\right)$. The melon seeds were dehulled and mixed with ash from burnt palm bunch to impart grey colour. It was then wrapped tightly with dried banana leaves, cooked for $3 \mathrm{~h}$ and allowed to cool. Using mortar and pestle already sterilized with $70 \%$ ethanol, cooked melon seeds were mashed. Fifteen grams $(15 \mathrm{~g})$ of the mashed melon seeds were wrapped separately using paper, leaves (banana), aluminium foil, black and transparent cellophanes after which the samples were enclosed in McCartney bottles and allowed to ferment for five (5) days at room temperature $\left(28 \pm 2{ }^{\circ} \mathrm{C}\right)$.

\section{Isolation of microorganisms from ogiri-egusi samples wrapped with different materials}

Standard microbiological methods were used to isolate bacteria and fungi from the fermented ogiri-egusi separately wrapped with different materials. The method described by Ojinnaka et al. (2013) with slight modification was adopted. In serial dilution of samples, the diluent used was peptone water. Its preparation involved dissolving $15 \mathrm{~g}$ of the powder in $1000 \mathrm{ml}$ distilled water using a sterile beaker. One gram $(1 \mathrm{~g})$ of ogiri-egusi wrapped in aluminium foil, paper, transparent and black cellophanes was aseptically 35 
homogenized separately in $9 \mathrm{ml}$ of peptone water using sterile conical flasks and thoroughly shaken. Aliquot $1 \mathrm{ml}$ of the dilutions from different conical flasks were transferred into $9 \mathrm{ml}$ of peptone water contained in sterile test tubes using different sterile pipette for each of the transfer carried out. From the dilution $\left(10^{-1}\right)$, the dilution $10^{-2}$ to $10^{-6}$ were prepared for each sample of ogiri-egusi in a particular wrapping material. Different sterile pipettes were used for each dilution to avoid contamination.

The following media were used for the isolation of microorganisms from the "ogiri-egusi" samples wrapped with different materials: Nutrient Agar (NA) for enumeration of bacterial isolates, MacConkey Agar (for enumeration of coliforms), Mannitol Salt Agar, MSA (for the isolation and identification of Staphylococcus aureus), Potato Dextrose Agar, PDA (for enumeration of yeast species) and deMan, Rogosa and Sharpe Agar, MRSA (for isolation of lactic acid bacteria). These media were prepared according to the manufacturer's instructions. Sterilization of the media involved autoclaving at $121^{\circ} \mathrm{C}$ and $15 \mathrm{psi}$ for 15 min, then allowed to cool to $45^{\circ} \mathrm{C}$, and plates were prepared in duplicates for each media. Lactic acid was added to the PDA plates to inhibit bacteria growth. $0.1 \mathrm{ml}$ from dilutions $10^{-2}$ and $10^{-3}$ for each sample of ogiri-egusi were inoculated into the Petri dishes containing the sterilized media and were spread aseptically using a sterile glass rod/ hockey stick/ glass spreader (near a flame). The inoculated plates (NA, MSA and MAC) were properly labelled and incubated at 37 ${ }^{\circ} \mathrm{C}$ for $24 \mathrm{~h}$ for bacterial growth. Meanwhile, the MRS culture plates were kept inside an anaerobic jar with a gas pack at $35 \pm 2{ }^{\circ} \mathrm{C}$, then the culture plates were incubated for $48 \mathrm{~h}$. The PDA culture plates were incubated at $37{ }^{\circ} \mathrm{C}$ for 3 days for fungal growth. On completion of the incubation periods, the colonies on the culture plates were counted, the microbial populations (Cfu/g) were calculated and converted to $\log _{10} \mathrm{Cfu} / \mathrm{g}$. The colonies were randomly picked with the aid of a sterilized inoculating loop and subcultured repeatedly using freshly prepared culture plates until pure colonies were obtained.

\section{Maintenance of pure isolates}

Repeated subculturing of the bacterial and fungal isolates were carried out on freshly prepared NA and PDA, respectively until pure isolates were obtained. The pure isolates were maintained on nutrient agar and potato dextrose agar slants which were stored at $4{ }^{\circ} \mathrm{C}$ (in a refrigerator) until confirmatory tests for the isolates was completed.

\section{E. Characterization and identification of the isolates}

The microorganisms were identified by cultural characteristics, microscopic and macroscopic examinations and through biochemical test. Features of the bacteria colonies such as colour, size, shape, elevation, edge, opacity was examined.

Bacterial isolates: Biochemical tests which involves catalase, indole, oxidase, methyl red, Voges-Proskauer, motility, Triple sugar iron, sugar fermentation and starch hydrolysis on each of the bacterial isolates were carried out using the procedure described by Umar et al. (2016). The bacterial isolates were subjected to Gram staining protocols described by Smith and Hussey (2006).

Fungal isolates: The mycelia growth observed on PDA culture plates were teased out and placed on two drops of Lactophenol on top of a clean glass slide. A coverslip was gently placed on top of the preparation and observed under the microscope using X10 and X40 objective lens. The morphological characteristics of fungi published by Watanabe (2010) was used as a guide in identifying the fungal isolates. Physically, the colour and structure of the mycelia was observed and the result was recorded. The septation, absence/presence of sporangiophores, rhizoids and fruiting bodies which forms part of the morphological structures was also observed and noted.

\section{F. Determination of microbial succession during fermentation}

The microbial succession was carefully monitored throughout the period of fermentation. This was carried out by using the five media NA, MSA, MRS, MAC, and PDA which were sterilized by autoclaving at $121^{\circ} \mathrm{C}$ for $20 \mathrm{~m}$ and used for culture. The autoclaved media were allowed to cool at $45^{\circ} \mathrm{C}$, Lactic acid was added to the PDA to inhibit bacteria growth. The media were poured into sterilized Petri plates in duplicates.

\section{G. Determination of $p H$}

One gram ( $1 \mathrm{~g})$ of the fermenting seeds was taken from each of the wrapping materials at the start of fermentation and at $24 \mathrm{~h}$ interval for 5 days. Each sample was weighed into a sterile mortar and mashed with clean beaker and $10 \mathrm{ml}$ of distilled water was added. It was mixed thoroughly to form slurry. A standard buffer solution ( $\mathrm{pH} \mathrm{6.0)}$ was prepared and this was used to standardize the $\mathrm{pH}$ meter (Dye Unicam, Model PW 9409). The electrode of the digital $\mathrm{pH}$ meter was dipped in the slurry. The $\mathrm{pH}$ readings were recorded.

\section{H. Proximate composition of ogiri-egusi samples}

The proximate compositions of fermented ogiri-egusi wrapped in different wrapping materials were determined using the Association of Official Analytical Chemists (AOAC) 2010 methods. Samples were analyzed for lipid, crude fiber, crude protein, moisture and ash content. The carbohydrate content was determined by difference.

\section{Sensory evaluation of ogiri-egusi samples}

Organoleptic evaluation of ogiri-egusi wrapped with different materials was carried out to determine consumer acceptance and preference using ten-man trained panelists from the university community using the procedure described by Ihekoronye and Ngoddy (1985). The sensory panelists evaluated the aroma, taste, colour and mouth feel of the samples using a 9-point Hedonic scale whereby lowest sensory score 1 is interpreted as 'dislike extremely' 
and highest sensory score 9 is interpreted as 'like extremely'. Nevertheless, precautions were taken to prevent interference in sensory properties of more than one sample evaluated by making sure panelists rinse their mouths with potable water after assessing each sample.

\section{J. Statistical analysis}

Analysis of variance (ANOVA) was used to statistically analyze data obtained from this study with the aid of software SPSS version 20. Turkey's least significant difference (LSD) was used for mean separation at $\mathrm{P}<0.05$ significant level.

\section{RESULTS}

Shown in Figure 1 is the picture of the fermented condiment product "ogiri-egusi.

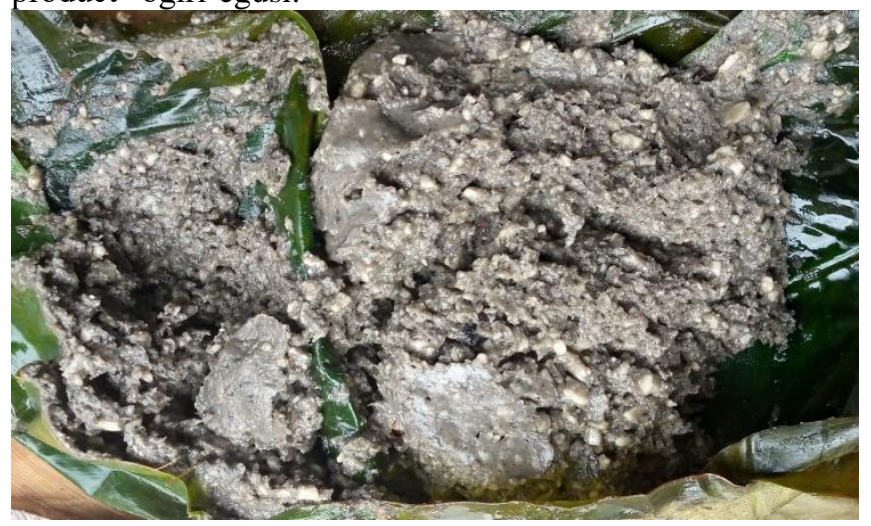

Figure 1. Fermented condiment product "ogiri-egusi wrapped with leaf

This study evaluated the microbiological quality, proximate composition, physicochemical and sensory properties of 'ogiri-egusi' (fermented melon) seeds (Citrullus vulgaris) wrapped with different materials. The result of the mean total heterotrophic bacterial count (THB) is presented in Figure 2. The mean THB count ranged from $5.8-6.08$ $\log _{10} \mathrm{CFU} / \mathrm{g}$ for the different wrapping materials. The highest mean THB count $\left(6.08 \log _{10} \mathrm{CFU} / \mathrm{g}\right)$ was observed in 'ogiri' wrapped with a leaf (L) whereas the lowest mean THB count (5.84 $\log _{10} \mathrm{CFU} / \mathrm{g}$ ) was obtained in 'ogiri' wrapped with aluminium foil (Af). There is a significant difference $(p<0.05)$ between mean THB count of 'ogiri' wrapped with different materials although there is no significant difference $(\mathrm{p}>0.05)$ exist between mean THB count of 'ogiri' wrapped with black cellophane $(\mathrm{Bc})$ and transparent cellophane $(\mathrm{Tc})$.

Figure 3 presents the mean total Coliform counts from ogiri samples wrapped with different materials. The mean total Coliform count obtained ranged from 4.39 - $4.88 \log _{10}$ CFU/g. Ogiri samples wrapped with leaf had the highest Coliform count (4.88 $\log _{10} \mathrm{CFU} / \mathrm{g}$ ) followed by samples wrapped with paper $\left(4.82 \log _{10} \mathrm{CFU} / \mathrm{g}\right)$ while the least mean Coliform count (4.39 $\log _{10} \mathrm{CFU} / \mathrm{g}$ ) was obtained in ogiri wrapped with aluminium foil. Analysis of variance result indicated that there is a significant difference $(p<0.05)$ between the mean total Coliform counts recorded for the different wrapping materials.

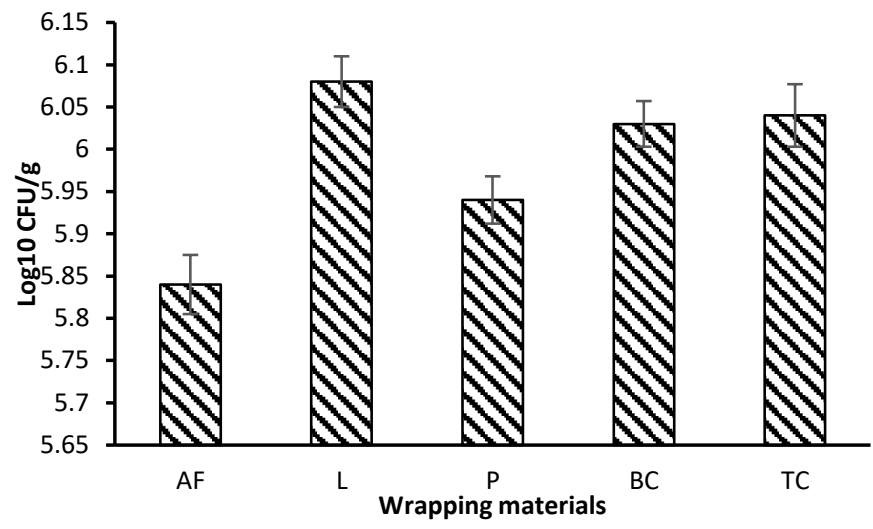

Figure 2. Mean total heterotrophic bacterial counts from ogiri-egusi samples wrapped with different materials. Keys: $A f=$ Aluminum foil, $L=$ Leaf, $\mathrm{P}=$ Paper, $\mathrm{Bc}=$ Black cellophane, $\mathrm{Tc}=$ Transparent cellophane.

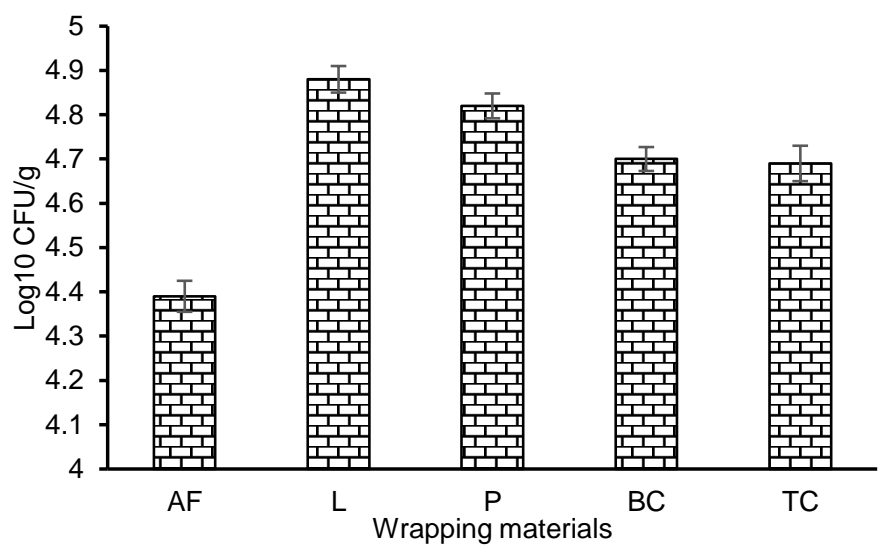

Figure 3. Mean total Coliform counts from (TCC) ogiri-egusi samples wrapped with different materials. Keys: $\mathrm{Af}=$ Aluminum foil, $\mathrm{L}=\mathrm{Leaf}, \mathrm{P}=$ Paper, $\mathrm{Bc}=$ Black cellophane, $\mathrm{Tc}=$ Transparent cellophane .

Mean total Staphylococcal count (TSC) is presented in Figure 4. The result indicated that the mean total Staphylococcal count obtained in the different wrapping materials ranged from $4.83-5.07 \log _{10} \mathrm{CFU} / \mathrm{g}$. Analysis of variance showed that there is no significant difference $(p<0.05)$ between mean total Staphylococcal count obtained in ogiri-egusi wrapped with different materials. The highest TSC was observed in ogiri-egusi wrapped with banana leaf (5.07 $\log _{10} \mathrm{CFU} / \mathrm{g}$ ) followed by samples wrapped with paper (5.04 $\log _{10} \mathrm{CFU} / \mathrm{g}$ ). The lowest mean TSC was recorded with ogiri-egusi wrapped with aluminium foil (4.83 $\log _{10} \mathrm{CFU} / \mathrm{g}$ ).

Figure 5 depicts the mean total Lactobacilli counts from ogiri samples wrapped with different materials. Result revealed that mean total Lactobacilli counts ranged between 3.61 - $3.94 \log _{10} \mathrm{CFU} / \mathrm{g}$. Ogiri wrapped with dried banana leaves and black cellophane (3.94 $\log _{10} \mathrm{CFU} / \mathrm{g}$, each) had the highest Lactobacilli counts followed closely by samples wrapped with transparent cellophane $\left(3.9 \mathrm{Log}_{10} \mathrm{CFU} / \mathrm{g}\right)$ and paper $\left(3.88 \log _{10} \mathrm{CFU} / \mathrm{g}\right)$. The lowest mean total 
Lactobacilli counts were obtained in ogiri wrapped with aluminium foil (Af). There is a significant difference $(p<0.05)$ between the mean total Lactobacilli counts obtained in all the wrapping materials although there is no significant difference $(\mathrm{p}>0.05)$ between the mean Lactobacilli counts obtained with leaf (L) and paper (P).

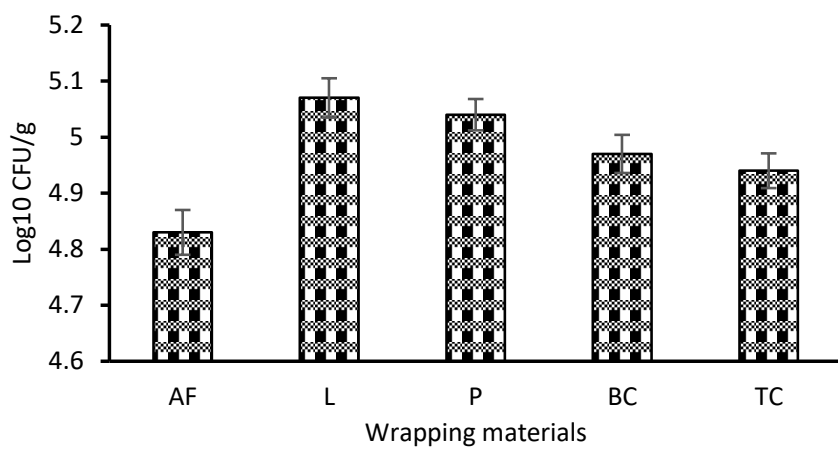

Figure 4. Mean total Staphylococcal counts (TSC) from ogiri-egusi wrapped with different materials. Keys: $\mathrm{Af}=$ Aluminum foil, $\mathrm{L}=\mathrm{Leaf}, \mathrm{P}=$ Paper, $\mathrm{Bc}=$ Black cellophane, $\mathrm{Tc}=$ Transparent cellophane

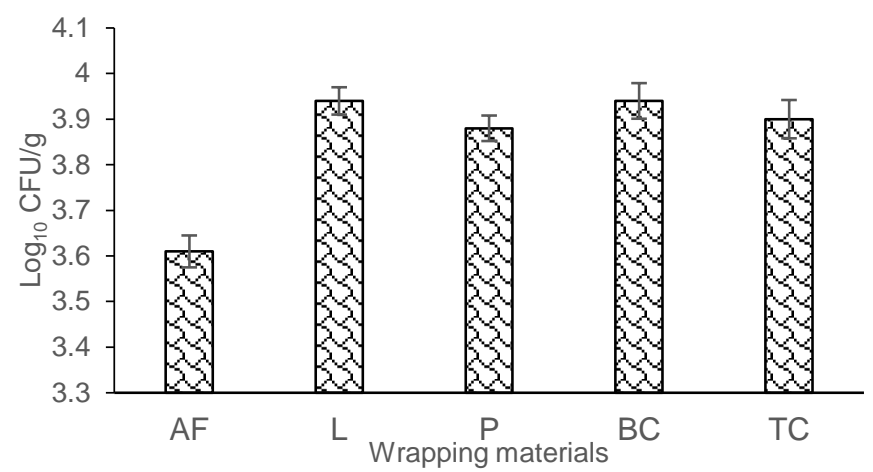

Figure 5. Mean total Lactobacilli counts (TLC) from ogiri samples wrapped with different materials. Keys: $\mathrm{Af}=$ Aluminum foil, $\mathrm{L}=\mathrm{Leaf}, \mathrm{P}=$ Paper, $\mathrm{Bc}$ $=$ Black cellophane, $\mathrm{Tc}=$ Transparent cellophane

Figure 6 shows the mean total fungal counts (TFC) from ogiri samples wrapped with different materials. This data revealed that mean total fungal count obtained in ogiri wrapped with different materials ranged from $3.39-3.75$ $\log _{10} \mathrm{CFU} / \mathrm{g}$. As presented in Figure 6, the highest mean TFC was observed in samples wrapped with dried banana leaf (3.75 $\log _{10} \mathrm{CFU} / \mathrm{g}$ ) which was followed by samples wrapped with black cellophane $\left(3.63 \log _{10} \mathrm{CFU} / \mathrm{g}\right)$ while the least count was seen in samples wrapped with aluminium foil. The analysis of variance indicated that there is a significant difference $(p<0.05)$ between the mean TFC recorded in ogiri wrapped with different materials.

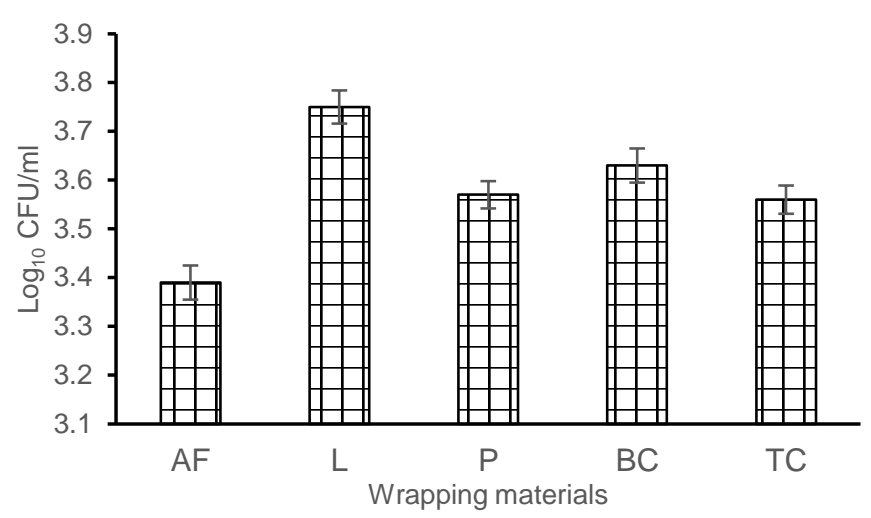

Figure 6. Mean total fungal counts (TFC) from ogiri samples wrapped with different materials. Keys: $\mathrm{Af}=$ Aluminum foil, $\mathrm{L}=$ Leaf, $\mathrm{P}=$ Paper, $\mathrm{Bc}=$ Black cellophane, Tc=Transparent cellophane

In Table 1, the biochemical characteristics of twenty-seven bacterial isolates from ogiri-egusi wrapped with different materials during the fermentation of the products revealed that they belong to four (4) bacterial genera, namely Staphylococcus sp. (Isolate Af3, L3, P2, Bc5 and Tc4), Micrococcus sp. (Isolate Af2, L1, L4, P4, P5 and Tc1), Bacillus sp. (Isolate Af1, Af4, Af5, L6, P1, Bc1, Bc2, Bc4, Tc2 and Tc5) and Lactobacillus sp. (Isolate L2, L5, L7, P3, $\mathrm{Bc} 3$ and Tc3). The result shows that Bacillus sp. was the dominant bacteria in the samples whereas Staphylococcus sp. was the least. All the bacterial genera were present in the ogiri- egusi samples wrapped with leaf, paper and transparent cellophane whereas only three bacterial genera were present in the samples wrapped with aluminium (Bacillus sp., Micrococcus sp. and Staphylococcus sp.) and black cellophane (Bacillus sp., Lactobacillus sp. and Staphylococcus sp.).

In Table 2, the cultural and morphological characteristics of fifteen fungal isolates obtained from samples of ogiri-egusi wrapped with different materials revealed that all the isolates belong to five fungal genera which are Aspergillus niger (Isolate Af1 and Tc2) and A. flavus (Isolate P3, L4 and L1), Fusarium sp. (Isolate L2), Saccharomyces sp. (Isolate Af2, L3, P1, Bc2 and Tc3), Penicillium sp. (Isolate Bc1 and $\mathrm{Bc} 3$ ) and Candida sp. (Isolate $\mathrm{P} 2$ and Tc1). Both Aspergillus sp. and Saccharomyces sp. were the dominant fungal genera whereas Fusarium sp. was the least. A total of three fungal genera were isolated from ogiri-egusi samples wrapped with leaf (Aspergillus flavus, Fusarium sp. and Saccharomyces sp.), paper (Saccharomyces sp., Candida sp. and A. flavus) and transparent cellophane (Candida sp., A. niger and Saccharomyces sp.) whereas the samples wrapped with black cellophane (Penicillium sp. and Saccharomyces sp.) and aluminium foil (A. niger and Saccharomyces sp.) had only two fungal genera. 
Table 1. Biochemical characteristics of bacteria isolated during fermentation of ogiri-egusi wrapped with different materials.

\begin{tabular}{|c|c|c|c|c|c|c|c|c|c|c|c|c|c|c|c|c|c|c|c|c|}
\hline \multirow{2}{*}{$\sum_{\sim}^{0}$} & \multirow{2}{*}{$\frac{0}{\frac{\pi}{0}} \frac{8}{0}$} & \multirow{2}{*}{ 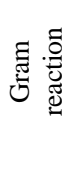 } & \multirow{2}{*}{ 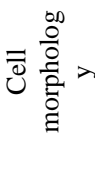 } & \multirow{2}{*}{$\stackrel{\Xi}{\Xi}$} & \multirow{2}{*}{$\begin{array}{l}\tilde{\Xi} \\
\frac{\tilde{J}}{\tilde{J}} \\
\tilde{J}\end{array}$} & \multirow{2}{*}{ 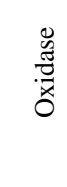 } & \multirow{2}{*}{$\frac{\frac{0}{0}}{\Xi}$} & \multirow{2}{*}{ 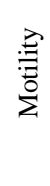 } & \multirow{2}{*}{$\underset{z}{\Sigma}$} & \multirow{2}{*}{$\frac{2}{3}$} & \multirow{2}{*}{ 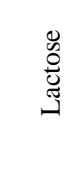 } & \multirow{2}{*}{$\begin{array}{l}\mathscr{D} \\
0 \\
0 \\
0 \\
0\end{array}$} & \multirow{2}{*}{ 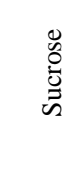 } & \multirow{2}{*}{ 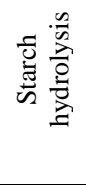 } & \multirow{2}{*}{ 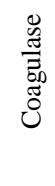 } & \multicolumn{4}{|c|}{ TSIA } & \multirow{2}{*}{ Probable organisms } \\
\hline & & & & & & & & & & & & & & & & Butt & Slant & $\mathrm{H}_{2} \mathrm{~S}$ & Gas & \\
\hline 1 & Af1 & + & Rod & + & + & - & - & + & - & + & $\mathrm{A}$ & $\mathrm{A}$ & - & + & - & B & $\mathrm{A}$ & - & - & Bacillus sp. \\
\hline 2 & Af2 & + & Cocci & + & - & + & - & - & + & - & $\mathrm{A} / \mathrm{G}$ & A & $\mathrm{A} / \mathrm{G}$ & A & A & + & - & + & - & Micrococcus sp. \\
\hline 3 & Af3 & + & Cocci & + & + & - & - & - & - & + & $\mathrm{A}$ & $\mathrm{A} / \mathrm{G}$ & - & + & + & B & A & - & - & Staphylococcus sp. \\
\hline 4 & Af4 & + & Rod & + & + & - & - & + & - & + & A & $\mathrm{A}$ & - & + & - & B & $\mathrm{A}$ & - & - & Bacillus sp. \\
\hline 5 & Af5 & + & Rod & + & + & - & - & + & - & + & A & $\mathrm{A}$ & - & + & - & B & $\mathrm{A}$ & - & - & Bacillus sp. \\
\hline 6 & L1 & + & Cocci & + & - & + & - & - & + & - & $\mathrm{A} / \mathrm{G}$ & $\mathrm{A}$ & $\mathrm{A} / \mathrm{G}$ & A & A & + & - & + & - & Micrococcus sp. \\
\hline 7 & L2 & + & Rod & - & - & - & - & - & - & + & $\mathrm{A} / \mathrm{G}$ & $\mathrm{A} / \mathrm{G}$ & - & - & - & $\mathrm{A}$ & A & - & - & Lactobacillus sp. \\
\hline 8 & L3 & + & Cocci & + & + & - & - & - & - & + & A & $\mathrm{A} / \mathrm{G}$ & - & + & + & B & A & - & - & Staphylococcus sp. \\
\hline 9 & $\mathrm{~L} 4$ & + & Cocci & + & - & + & - & - & + & - & $\mathrm{A} / \mathrm{G}$ & $\mathrm{A}$ & $\mathrm{A} / \mathrm{G}$ & A & A & + & - & + & - & Micrococcus sp. \\
\hline 10 & L5 & + & Rod & - & - & - & - & - & - & + & $\mathrm{A} / \mathrm{G}$ & $\mathrm{A} / \mathrm{G}$ & - & - & - & A & $\mathrm{A}$ & - & - & Lactobacillus sp. \\
\hline 11 & L6 & + & Rod & + & + & - & - & + & - & + & A & $\mathrm{A}$ & - & + & - & B & A & - & - & Bacillus sp. \\
\hline 12 & L7 & + & Rod & - & - & - & - & - & - & + & $\mathrm{A} / \mathrm{G}$ & $\mathrm{A} / \mathrm{G}$ & - & - & - & $\mathrm{A}$ & $\mathrm{A}$ & - & - & Lactobacillus sp. \\
\hline 13 & $\mathrm{P} 1$ & + & Rod & + & + & - & - & + & - & + & A & $\mathrm{A}$ & - & + & - & B & A & - & - & Bacillus sp. \\
\hline 14 & $\mathrm{P} 2$ & + & Cocci & + & + & - & - & - & - & + & A & $\mathrm{A} / \mathrm{G}$ & - & + & + & B & A & - & - & Staphylococcus sp. \\
\hline 15 & P3 & + & Rod & - & - & - & - & - & - & + & $\mathrm{A} / \mathrm{G}$ & $\mathrm{A} / \mathrm{G}$ & - & - & - & A & A & - & - & Lactobacillus sp. \\
\hline 16 & $\mathrm{P} 4$ & + & Cocci & + & - & + & - & - & + & - & $\mathrm{A} / \mathrm{G}$ & $\mathrm{A}$ & $\mathrm{A} / \mathrm{G}$ & $\mathrm{A}$ & A & + & - & + & - & Micrococcus sp. \\
\hline 17 & P5 & + & Cocci & + & - & + & - & - & + & - & $\mathrm{A} / \mathrm{G}$ & $\mathrm{A}$ & $\mathrm{A} / \mathrm{G}$ & A & A & + & - & + & - & Micrococcus sp. \\
\hline 18 & $\mathrm{Bc} 1$ & + & Rod & + & + & - & - & + & - & + & A & $\mathrm{A}$ & - & + & - & B & $\mathrm{A}$ & - & - & Bacillus sp. \\
\hline 19 & $\mathrm{Bc} 2$ & + & Rod & + & + & - & - & + & - & + & A & $\mathrm{A}$ & - & + & - & B & $\mathrm{A}$ & - & - & Bacillus sp. \\
\hline 20 & $\mathrm{Bc} 3$ & + & Rod & - & - & - & - & - & - & + & $\mathrm{A} / \mathrm{G}$ & $\mathrm{A} / \mathrm{G}$ & - & - & - & $\mathrm{A}$ & $\mathrm{A}$ & - & - & Lactobacillus sp. \\
\hline 21 & $\mathrm{Bc} 4$ & + & Rod & + & + & - & - & + & - & + & A & $\mathrm{A}$ & - & + & - & B & $\mathrm{A}$ & - & - & Bacillus sp. \\
\hline 22 & Bc5 & + & Cocci & + & + & - & - & - & - & + & $\mathrm{A}$ & $\mathrm{A} / \mathrm{G}$ & - & + & + & B & A & - & - & Staphylococcus sp. \\
\hline 23 & $\mathrm{Tc} 1$ & + & Cocci & + & - & + & - & - & + & - & $\mathrm{A} / \mathrm{G}$ & A & $\mathrm{A} / \mathrm{G}$ & A & A & + & - & + & - & Micrococcus sp. \\
\hline 24 & $\mathrm{Tc} 2$ & + & Rod & + & + & - & - & + & - & + & $\mathrm{A}$ & A & - & + & - & B & A & - & - & Bacillus sp. \\
\hline 25 & $\mathrm{Tc} 3$ & + & Rod & - & - & - & - & - & - & + & $\mathrm{A} / \mathrm{G}$ & $\mathrm{A} / \mathrm{G}$ & - & - & - & A & $\mathrm{A}$ & - & - & Lactobacillus sp. \\
\hline 26 & $\mathrm{Tc} 4$ & + & Cocci & + & + & - & - & - & - & + & A & $\mathrm{A} / \mathrm{G}$ & - & + & + & B & $\mathrm{A}$ & - & - & Staphylococcus sp. \\
\hline 27 & $\mathrm{Tc} 5$ & + & Rod & + & + & - & - & + & - & + & $\mathrm{A}$ & $\mathrm{A}$ & - & + & - & $\mathrm{B}$ & A & - & - & Bacillus sp. \\
\hline
\end{tabular}

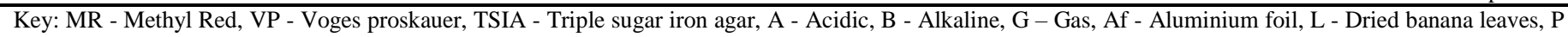

- Paper, Bc - Black cellophane, Tc - Transparent cellophane

Table 2. Cultural and morphological characteristics of fungi isolated during fermentation of ogiri-egusi wrapped with different materials

\begin{tabular}{|c|c|c|c|c|}
\hline S/No. & Isolate code & Cultural characteristics & Cell morphology & Probable organisms \\
\hline 1 & Af1 & Black powdery surface about $6 \mathrm{~mm}$ & $\begin{array}{l}\text { Septate branched mycelium, conidia in chains sterignatasing } \\
\text { strand septate }\end{array}$ & Aspergillus niger \\
\hline 2 & Af2 & $\begin{array}{l}\text { Dull white, smooth and moist colonies } \\
\text { which are raised }\end{array}$ & Oval to round large elipsidal budding yeast like & Saccharomyces sp. \\
\hline 3 & L1 & Green powdery surface about $6 \mathrm{~mm}$ & Septate, branched mycelia & Aspergillus flavus \\
\hline 4 & $\mathrm{~L} 2$ & $\begin{array}{l}\text { Dull, whitish in colour and has rough } \\
\text { colonies }\end{array}$ & Oval shaped with hyphae & Fusarium sp. \\
\hline 5 & L3 & $\begin{array}{l}\text { Dull white, smooth and moist colonies } \\
\text { which are raised }\end{array}$ & Oval to round large elipsidal budding yeast like & Saccharomyces sp. \\
\hline 6 & L4 & Green powdery surface about $6 \mathrm{~mm}$ & Septate, branched mycelia & Aspergillus flavus \\
\hline 7 & $\mathrm{P} 1$ & $\begin{array}{l}\text { Dull white, smooth and moist colonies } \\
\text { which are raised }\end{array}$ & Oval to round large elipsidal budding yeast like & Saccharomyces sp. \\
\hline 8 & $\mathrm{P} 2$ & Dull white, rough colonies & Oval shaped with hyphae & Candida sp. \\
\hline 9 & $\mathrm{P} 3$ & Green powdery surface about $6 \mathrm{~mm}$ & Septate, branched mycelia & Aspergillus flavus \\
\hline 10 & $\mathrm{Bc} 1$ & Green velvety like colony about $6 \mathrm{~mm}$ & $\begin{array}{l}\text { Hyphae consist of a highly branched network of multinucleate } \\
\text { septate with mycelia containing conidiosphores }\end{array}$ & Penicillium sp. \\
\hline 11 & $\mathrm{Bc} 2$ & $\begin{array}{l}\text { Dull white, smooth and moist colonies } \\
\text { which are raised }\end{array}$ & Oval to round large elipsidal budding yeast like & Saccharomyces sp. \\
\hline 12 & $\mathrm{Bc} 3$ & Green velvety like colony about $6 \mathrm{~mm}$ & $\begin{array}{l}\text { Hyphae consist of a highly branched network of multinucleate } \\
\text { septate with mycelia containing conidiosphores }\end{array}$ & Penicillium sp. \\
\hline 13 & $\mathrm{Tc} 1$ & Dull white, rough colonies & Oval shaped with hyphae & Candida sp. \\
\hline 14 & $\mathrm{Tc} 2$ & Black powdery surface about 6mm & $\begin{array}{l}\text { Septate branched mycelium, conidia in chains sterignatasingl } \\
\text { strand septate }\end{array}$ & Aspergillus niger \\
\hline 15 & $\mathrm{Tc} 3$ & $\begin{array}{l}\text { Dull white, smooth and moist colonies } \\
\text { which are raised }\end{array}$ & Oval to round large elipsidal budding yeast like & Saccharomyces sp. \\
\hline
\end{tabular}

Keys: Af - Aluminum foil, L - Dried banana leaves, P - Paper, Bc - Black cellophane, Tc - Transparent cellophane 
In Figure 7, the $\mathrm{pH}$ of ogiri-egusi wrapped with different materials monitored at $24 \mathrm{~h}$ interval during the fermentation period was within the range of 6.05-7.12. Generally, the $\mathrm{pH}$ of the samples wrapped with different materials slightly increased with an increase in fermentation time. They all showed a similar pattern of $\mathrm{pH}$ variation during the fermentation process. This trend indicated that irrespective of the material used in wrapping the ogiri-egusi, they possess a similar $\mathrm{pH}$ range of adequate fermentation.

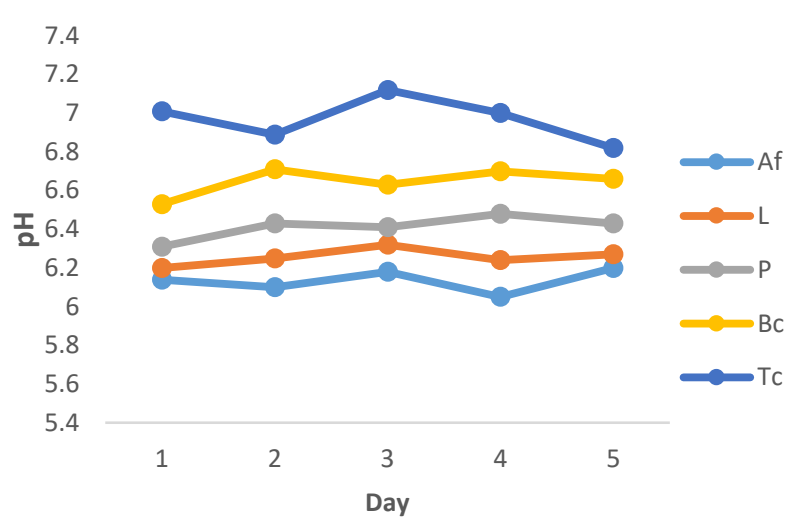

Figure 7. $\mathrm{pH}$ of ogiri-egusi wrapped with different materials monitored during fermentation. Key: Af - Aluminum foil, L- Dried banana leaves, P - Paper, Bc - Black cellophane, Tc - Transparent cellophane.

Depicted in Table 3 is the proximate composition of ogiriegusi wrapped with different materials. This result shows that the crude protein content of ogiri-egusi wrapped with different materials ranged from $28.04 \pm 1.22-32.31 \pm 1.83 \%$. Also, the result showed that there is no significant difference between crude protein content in ogiri-egusi wrapped with Af, P, Bc and Tc but differed with the value for ogiri-egusi wrapped with L which had the lowest crude protein content $(28.04 \pm 1.22 \%)$. The ash content ranged from $2.10 \pm 0.23$ to $3.09 \pm 0.12 \%$ with least ash content recorded with ogiri-egusi wrapped with aluminium foil. There is no significant difference $(p>0.05)$ between the mean ash content obtained in ogiri-egusi samples wrapped with $\mathrm{L}, \mathrm{P}, \mathrm{Bc}$ and Tc. The crude fibre content of ogiri-egusi wrapped with different materials ranged from $1.95 \pm 0.21-3.87 \pm 0.24 \%$. Also, the result indicated that ogiri-egusi wrapped with paper $(\mathrm{P})$ and black cellophane $(\mathrm{Bc})$ had the lowest crude fibre content of $1.95 \pm 0.21 \%$ and $1.97 \pm 1.97 \pm 0.36 \%$, respectively. The crude fibre content of ogiri wrapped with Af, L, and Tc were not significant $(p>0.05)$ among them, while significantly $(p<0.05)$ compared with $\mathrm{P}$ and $\mathrm{Bc}$. The moisture content ranged from $33.68 \pm 1.02-37.50 \pm 1.46 \%$ with the highest obtained in ogiriegusi wrapped Af and L (37.50 \pm 1.46 and $36.75 \pm 1.29$, respectively) which were significantly $(\mathrm{p}=0.05)$ equal. The lipid content ranged from $20.78 \pm 0.86$ to $24.29 \pm 0.80 \%$ and the highest was recorded in ogiri-egusi wrapped with $\mathrm{Bc}$ and $\mathrm{P}$ (which are significantly $(\mathrm{p}=0.05$ ) equal). Lowest lipid content was observed in ogiri-egusi wrapped with Af $(20.78 \pm 0.86 \%)$. The carbohydrate content which ranged from $3.89 \pm 2.14$ $5.29 \pm 1.37 \%$ had the lowest value with ogiri-egusi wrapped in Af $(3.89 \pm 2.14 \%)$. There is no significant difference $(p>0.05)$ between carbohydrate content of ogiri wrapped with L, P, Bc and $\mathrm{Tc}$, although they were higher than the carbohydrate content in ogiri wrapped with Af.

Table 3. Proximate composition (\%) of ogiri-egusi wrapped with different materials

\begin{tabular}{cccccc}
\hline \multicolumn{7}{c}{ Packaged Samples } \\
\hline Parameters & Af & $\mathrm{L}-+9$ & $\mathrm{P}$ & $\mathrm{Bc}$ & $\mathrm{Tc}$ \\
\hline \multirow{2}{*}{ Crude protein } & $32.31 \pm$ & $28.04 \pm$ & $32.21 \pm$ & $31.48 \pm$ & $32.27 \pm$ \\
& $1.83^{\mathrm{b}}$ & $1.22^{\mathrm{a}}$ & $1.08^{\mathrm{b}}$ & $1.41^{\mathrm{b}}$ & $1.39^{\mathrm{b}}$ \\
Ash & $2.10 \pm$ & $3.09 \pm$ & $2.98 \pm$ & $2.64 \pm$ & $2.93 \pm$ \\
& $0.23^{\mathrm{a}}$ & $0.12^{\mathrm{b}}$ & $0.35^{\mathrm{b}}$ & $0.26^{\mathrm{b}}$ & $0.19^{\mathrm{b}}$ \\
Crude fibre & $3.43 \pm$ & $3.62 \pm$ & $1.95 \pm$ & $1.97 \pm$ & $3.87 \pm$ \\
& $0.48^{\mathrm{b}}$ & $0.45^{\mathrm{b}}$ & $0.21^{\mathrm{a}}$ & $0.36^{\mathrm{a}}$ & $0.24^{\mathrm{b}}$ \\
Moisture & $37.50 \pm$ & $36.75 \pm$ & $33.68 \pm$ & $34.61 \pm$ & $33.69 \pm$ \\
& $1.46^{\mathrm{c}}$ & $1.29^{\mathrm{bc}}$ & $1.02^{\mathrm{a}}$ & $1.41^{\mathrm{ab}}$ & $1.44^{\mathrm{a}}$ \\
Lipid & $20.78 \pm$ & $23.22 \pm$ & $24.26 \pm$ & $24.29 \pm$ & $22.64 \pm$ \\
& $0.86^{\mathrm{a}}$ & $0.77^{\mathrm{bc}}$ & $0.77^{\mathrm{c}}$ & $0.80^{\mathrm{c}}$ & $0.83^{\mathrm{b}}$ \\
Carbohydrate & $3.89 \pm$ & $5.29 \pm$ & $4.92 \pm$ & $5.02 \pm$ & $4.60 \pm$ \\
& $2.14^{\mathrm{a}}$ & $1.37^{\mathrm{b}}$ & $2.35^{\mathrm{b}}$ & $3.09^{\mathrm{b}}$ & $3.97^{\mathrm{b}}$ \\
\hline
\end{tabular}

Values show the means of triplicate analysis \pm SD. Values with different superscript across the row, are significantly different $(\mathrm{P}<0.05)$. Key: Af Aluminum foil, L-Dried banana leaves, P - Paper, Bc - Black cellophane, Tc Transparent cellophane.

Table 4 depicts the sensory evaluation of ogiri-egusi wrapped with different materials. The result showed that the colour of the ogiri-egusi wrapped with different materials were rated from liked slightly (6) to like very much (8). The samples wrapped with Af had a mean value of $8.11 \pm 0.67$ (Liked very much) while samples wrapped with $\mathrm{Bc}$ and $\mathrm{Tc}$ had lowest mean value of $6.37 \pm 1.15$ and $6.09 \pm 0.94$, respectively (slightly liked) concerning colour. On taste, the samples were rated neither liked nor disliked (5), liked slightly (6), liked moderately (7) or liked very much (8).

Table 4. Sensory evaluation of ogiri-egusi wrapped with different materials

\begin{tabular}{ccccc}
\hline $\begin{array}{c}\text { Sample } \\
\text { code }\end{array}$ & Colour & Taste & Aroma & Mouth feel \\
\hline Af & $8.11 \pm 0.67^{\mathrm{b}}$ & $8.24 \pm 1.05^{\mathrm{c}}$ & $7.17 \pm 0.94^{\mathrm{c}}$ & $7.00 \pm 1.05^{\mathrm{c}}$ \\
L & $7.04 \pm 1.15^{\mathrm{ab}}$ & $7.00 \pm 1.25^{\mathrm{b}}$ & $6.23 \pm 0.82^{\mathrm{b}}$ & $7.12 \pm 0.82^{\mathrm{c}}$ \\
P & $7.22 \pm 1.49^{\mathrm{ab}}$ & $6.31 \pm 1.25^{\mathrm{a}}$ & $5.00 \pm 0.82^{\mathrm{a}}$ & $5.06 \pm 0.82^{\mathrm{a}}$ \\
Bc & $6.37 \pm 1.15^{\mathrm{a}}$ & $5.31 \pm 1.05^{\mathrm{a}}$ & $7.07 \pm 0.67^{\mathrm{c}}$ & $6.32 \pm 1.15^{\mathrm{b}}$ \\
Tc & $6.09 \pm 0.94^{\mathrm{a}}$ & $5.10 \pm 0.82^{\mathrm{a}}$ & $7.13 \pm 1.15^{\mathrm{c}}$ & $6.04 \pm 1.05^{\mathrm{b}}$ \\
\hline
\end{tabular}

Values show means of sensory scores of ten panelists \pm SD. Values with different superscript down the column, are significantly different $(\mathrm{P}<0.05)$. Key: Af = Aluminum foil, $\mathrm{L}=$ Dried banana leaves, $\mathrm{P}=$ Paper, $\mathrm{Bc}=$ Black cellophane, $\mathrm{Tc}=$ Transparent cellophane. Sensory score: $9=$ Like extremely, $8=$ Like very much $7=$ Like moderately $6=$ Like slightly, $5=$ Neither like nor dislike, 4 = Dislike slightly, 3 = Dislike moderately, 2 = Dislike very much, 1 $=$ Dislike extremely.

Sensory results show that there was no significant difference $(p>0.05)$ in taste between the samples wrapped with $\mathrm{Bc}, \mathrm{Tc}$ and $\mathrm{P}$ which were neither liked nor disliked (5). Samples wrapped with Af were given the highest score of $8.24 \pm 1.05$ 
(liked very much) while samples wrapped with $\mathrm{L}$ had a score of approximately 7.0 (liked moderately). For aroma, there is no significant difference $(\mathrm{p}>0.05)$ between scores given to samples wrapped with Af, Bc, and Tc which had approximately 7 (liked moderately) while samples wrapped with $\mathrm{L}$ was rated liked slightly $(6.23 \pm 0.82)$. The lowest score of 5 was given to samples wrapped with $\mathrm{P}$ (neither liked nor disliked). Results also showed that mouth feel of the samples was rated between neither liked nor disliked (5) and liked moderately (7). The mouth feel of the samples were significantly equal $(p=0.05)$ for ogiri-egusi wrapped with Af and L which were moderately liked (7). The mouth feel of the samples were significantly $(\mathrm{p}=0.05)$ similar for Af and $\mathrm{L}$ which were moderately liked (7) whereas there was no significant difference $(\mathrm{p}>0.05)$ between mean score for $\mathrm{Bc}$ and Tc rated slightly liked (6). Samples wrapped with $\mathrm{P}$ had the lowest score of 5.06 \pm 0.82 (neither liked nor disliked).

\section{DISCUSSION}

Microbiological analysis of ogiri-egusi separately wrapped with aluminium foil, dried banana leaves, paper, black and transparent cellophane after 5 days of fermentation revealed that the samples wrapped with dried banana leaves had the highest total heterotrophic bacterial count (THC 6.08 $\log _{10} \mathrm{CFU} / \mathrm{g}$ ), total coliform count (TCC $4.88 \log _{10} \mathrm{CFU} / \mathrm{g}$ ), total staphylococcal count (TSC $5.07 \log _{10} \mathrm{CFU} / \mathrm{g}$ ) and total fungal count (TFC $3.75 \log _{10} \mathrm{CFU} / \mathrm{g}$ ). This could be as a result of dried banana leaves used in wrapping ogiri-egusi were previously exposed to microbial contamination in the environment. Meanwhile, total lactobacilli count (TLC 3.94 $\log _{10} \mathrm{CFU} / \mathrm{g}$ ) of ogiri-egusi separately wrapped with leaves and black cellophane had the same value which was higher than that of other samples wrapped with different materials. On the contrary, ogiri-egusi wrapped with aluminum foil had the lowest THC (5.84 $\log _{10} \mathrm{CFU} / \mathrm{g}$ ), TCC (4.39 $\log _{10} \mathrm{CFU} / \mathrm{g}$ ), TSC (4.83 $\left.\log _{10} \mathrm{CFU} / \mathrm{g}\right)$, TLC (3.61 $\left.\log _{10} \mathrm{CFU} / \mathrm{g}\right)$ and TFC (3.39 $\log _{10} \mathrm{CFU} / \mathrm{g}$ ). This could be as a result of good manufacturing practices (GMP) involved during the production of aluminium foil. Also, the aluminium foil not being directly exposed to microbial contamination in the environment during handling until it was used for wrapping ogiri-egusi could also have contributed to low microbial load of the fermented food product unlike other wrapping materials used for this study. This result is in agreement with a similar study carried out by Peter-Ikechukwu et al. (2015) which reported that total viable count of ogiri-egusi wrapped with aluminium foil after $72 \mathrm{~h}$ fermentation was $6.98 \log _{10} \mathrm{CFU} / \mathrm{g}$ whereas other products wrapped with unblanched leaves, blanched leaves, dried leaves, transparent and black polyethylene were within the range 7.16-7.39 $\log _{10} \mathrm{CFU} / \mathrm{g}$.

Our study revealed that bacterial isolates obtained from ogiriegusi wrapped with different wrapping materials were Staphylococcus sp., Micrococcus sp., Bacillus sp. and Lactobacillus sp. whereas fungal and yeast isolates were Aspergillus niger, A. flavus, Fusarium sp., Saccharomyces sp., Penicillium sp. and Candida sp. According to Olasupo and
Okorie (2019), most of the bacterial species isolated from ogiri-egusi are associated with fermentation of legumes and oil bean seeds for production of condiments. Consistently, several studies have reported that Bacillus sp. which have proteolytic activity is commonly found in fermenting mash of different condiments (Olanbiwoninu and Odunfa, 2018). The involvement of metabolic and enzymatic hydrolytic activities of Bacillus sp. during fermentation of condiments breakdown available proteins into amino acids. However, the presence of certain species of Bacillus sp. such as B. cereus in fermented condiments is an indication that poor hygienic practices were involved during production (Ibeabuchi et al., 2014). Probable sources of Bacillus sp. in samples of ogiri-egusi could be from air or wrapping materials (Akinyele and Oloruntoba, 2013). Staphylococcus and Micrococcus spp. have a lesser role in the fermentation of condiments than Bacillus sp. (Olasupo and Okorie, 2019). Lactic acid bacteria (LAB) possess the ability to grow in food substrates despite being fastidious on artificial media. The growth of LAB lowers the $\mathrm{pH}$ of the substrate which inhibits the growth of competing microorganism (Olanbiwoninu and Odunfa, 2018). In a related study, PeterIkechukwu et al. (2015) identified Bacillus sp., Enterococcus faecalis and Saccharomyces cerevisiae from fermented melon seeds (Citrullus vulgaris L. seed) locally known as 'ogiri' wrapped with different materials. Lactobacillus plantarum, $L$. jenseni, L. fermenti, L. casei, Leuconostoc cremoris, Bacillus sphaericus, B. mycoides, Staphylococcus aureus were also isolated by Akinyele and Oloruntoba (2013) during melon seed fermentation for production of ogiri.

During fermentation of ogiri-egusi wrapped with aluminium foil, leaves, paper and black cellophane, our results revealed that slight variations in $\mathrm{pH}$ of the samples occurred which were within the range 6.05-6.71. It was a similar trend with ogiri-egusi wrapped with transparent cellophane but the values were slightly higher (6.82-7.12). This result is in agreement with the study reported by Azi et al. (2017). Varied fermentation time could be the reason for variation in $\mathrm{pH}$ of the various samples of ogiri-egusi wrapped with different materials. According to Azi et al. (2017), fermentation time significantly affects the $\mathrm{pH}$ of traditionally fermented protein condiments. Besides, the variety of melon seeds which influences the chemical composition of the seeds could as well influence their $\mathrm{pH}$. Notably, the $\mathrm{pH}$ of all the samples of ogiriegusi wrapped with different wrapping materials at Day 1 was slightly lower than the values at Day 5 except the sample wrapped with transparent cellophane. The increase in $\mathrm{pH}$ could be attributed to hydrolysis of protein into amino acids which increasingly occurred during fermentation. This could be responsible for strong ammonical odour and flavour associated with the final product which also plays an important role in extending its shelf life (Ibeabuchi et al., 2014). The intervals slight reduction in $\mathrm{pH}$ occurred during fermentation of ogiri-egusi wrapped with different materials could be as a result of organic acids produced as a result of carbohydrate utilization by microorganisms (Ogueke et al., 2013). 
In terms of proximate composition of samples of ogiri-egusi wrapped with different materials, our results revealed that there were more significant differences for each of the parameters with few exceptions including carbohydrate content. Ogiri-egusi wrapped with aluminium foil had the highest protein content $(32.31 \%)$ and moisture content $(37.50$ $\%)$ when compared with other samples wrapped with different materials. The highest moisture content of ogiri-egusi wrapped with aluminium foil compared with other samples wrapped with different materials is in agreement with a related study carried out by Peter-Ikechukwu et al. (2015). This could be attributed to the non-porous property of aluminium foil. Generally, the microbial quality of any processed food is affected by moisture content. Any food product with high moisture content is predisposed to fast microbial spoilage and short shelf life (Azi et al., 2017). During fermentation, it is most likely that various microorganisms utilize nutritional components of the fermenting mash and convert them into products which influences its chemical composition and taste (Olasupo and Okorie, 2019). The moisture, protein, lipid and ash content of ogiri-egusi separately wrapped with dried banana leaves, aluminium foil, paper, transparent and black cellophane is comparable with the results reported by PeterIkechukwu et al. (2015) from a related study.

Based on scores in the sensory quality of all the ogiri-egusi samples wrapped with different materials, the sensory panelists reported that the fermented product wrapped with aluminium foil was most preferred. The colour and taste of ogiri-egusi wrapped with aluminium foil were very much liked by the sensory panelist while its aroma and mouth feel were liked moderately. This result partially agrees with PeterIkechukwu et al. (2015) which reported that ogiri-egusi wrapped with aluminium foil and black polyethylene bags were preferred than samples wrapped with transparent polyethylene, dried, blanched and unblanched leaves. Sensory evaluation of all the ogiri-egusi samples wrapped with different materials revealed that the product wrapped with dried banana leaves was the second best. According to Kabuo et al. (2015), ogiri-egusi wrapped with banana leaves was assigned highest sensory scores in terms of colour, aroma and texture compared with the product separately wrapped with miracle fruit leaves and cocoyam leaves. In terms of proximate composition and sensory data, Kabuo et al. (2015) reported that banana leaves were the most preferred wrapping material for ogiri-egusi compared with miracle fruit leaves and cocoyam leaves. Statistical analysis of sensory scores of ogiriegusi wrapped with different materials revealed that there is no significant difference in terms of colour, taste, aroma and mouth-feel between ogiri-egusi wrapped in black cellophane and ogiri-egusi wrapped in transparent cellophane. This could be as a result of using a material (cellophane) which has similar structural properties to wrap ogiri-egusi. However, there is a significant difference between ogiri-egusi wrapped with aluminium foil and ogiri-egusi wrapped with dried banana leaves in terms of sensory properties except for mouth feel.

\section{V.CONCLUSION}

Staphylococcus sp., Micrococcus sp., Bacillus sp., Lactobacillus sp Aspergillus niger, A. flavus, Fusarium sp., Saccharomyces sp., Penicillium sp. and Candida sp. were isolated from ogiri-egusi wrapped with aluminum foil, dried banana leaves, paper, black and transparent cellophane. Ogiriegusi wrapped with aluminium foil and dried banana leaves had the lowest and highest microbial population, respectively. There were variations in proximate composition of ogiri-egusi wrapped with different materials and their $\mathrm{pH}$ values slightly increased during fermentation with few exceptions. Sensory evaluation of the samples showed that ogiri-egusi wrapped with aluminium foil was most preferred. Based on the microbial analysis, proximate composition and sensory properties of ogiri-egusi wrapped with different materials, aluminium foil is recommended. Therefore, the utilization of aluminium foil as wrapping material for ogiri-egusi could potentially enhance the microbial and aesthetic qualities of the local fermented product thereby increasing its acceptability among individuals of various social status.

\section{REFERENCES}

Achi, O.K., Okereka, E.G. (1999). Proximate composition and functional properties of Prosopis africana seed flour. Journal Management Technology, 1, 7-13.

Adegunloye, D.V., Agarry, O.O., Adebolu, T.T., Adetuyi, F.C. (2006). Effect of leaf-packaging on the microbiological assessment of some food items. African Journal of Biotechnology, 5(5), 445-447.

Akinyele, B.J., Oloruntoba, O.S. (2013). Comparative studies on Citrullus vulgaris, Citrullus colocynthis and Cucumeropsis mannii for ogiri production. British Microbiology Research Journal, 3(1), 1-18.

AOAC (2010). Official Methods of Analysis. 20th ed., Association of Official Analytical Chemist. Washington DC, USA.

Azi, F., Odo, M.O., Okorie, P.A., Njoku, H.A., Nwobasi, V.N., Nwankwegu, A. S. (2017). Fungi and aflatoxin analysis of processed ogiri-egusi and ogiri-ugba consumed in Abakiliki metropolis. African Journal of Biotechnology, 16(42), 2024 -2030.

Barber, L., Achinewhu, S.C., Ibiama, E.M. (1988). The microbiology of ogiri production from castor seeds (Ricinus communis). Food Microbiology, 5, 177-182.

Barber, L.A., Achinewhu, S.C. (1992). Microbiology of ogiri production from melon seeds (Citrullus vulgaris). Nigerian Journal of Microbiology, 10, 129-135.

Barimalaa, I.S., Achinewhu, S.C., Yibatima, I., Amadi, E.N. (1989). Studies on the solid substrate fermentation of bambara groundnut (Vigna subterranea (L) Verdc). Journal Science of Food Agriculture, 66, 443446.

Chukwu, M.N., Nwakodo, C.S, Alozie, Q. (2018). Comparative studies on organoleptic properties of ogiri-ahuekere and ogiri-egusi condiments. Research Journal of Food Science and Quality Control, 4(1), 11- 19.

Chukwu, M.N., Ezeagwula, C.G., Nwakaudu, A.A., Oti, W., Anyaogu, I. (2019). Microbial loads of ogiri-ahuekere condiment produced from groundnut seed (Arachis hypogaea Linn). Agriculture and Food Sciences Research, 6 (1), 114-119.

Egbebi, A.O., Seidu, K.T., Muhammad, A.A. (2016). Nutritional and microbiological analyses of fermented locust beans (Parkia biglobosa) and fermented melon (Citrullus vulgaris). Savant Journal of Agricultural Research, 2(1), 001-006.

Ibeabuchi, J. C., Olawuni, I. A., Iheagwara, M. C., Ojukwu, M., Ofoedu, C. E. (2014). Microbiological evaluation of 'Iru' and 'ogiri-isi' used as food condiments. IOSR Journal of Environmental Science, Toxicology and Food Technology, 8(8)1, 45-50.

Ihekoronye, A.I., Ngoddy, P.O. (1985). Integrated Food Science and Technology for the Tropics. Macmillan, London Pp. 280-281. 
Kabuo, N.O., Asoegwu, S.N., Omeire, G.C., Bede, E.N., Peter-Ikechukwu, A.I., Akajiaku, L.O., Nwanesi, C.V. (2015). Effect of leaves-type on the nutritive and organoleptic properties of ogiri-egusi (fermented Citrullus vulgaris) seeds. Asian Journal of Agriculture and Food Sciences, 3(1), 61-67.

Ogbuonye, E.O. (2018). Chemical and microbial evaluation of 'ogiri' (A locally fermented food condiment) produced from kersting groundnut seeds. Science Arena Publications Specialty Journal of Biological Sciences, 4(2), 7-13.

Ogueke, C.C., Okoli, A.I., Owuamanam, C.I., Ahaotu, I. (2013). Fermentation of melon seeds for 'Ogiri egusi' as affected by fermentation variables using Bacillus subtilis. Malaysian Journal of Microbiology, 9(4), 279288.

Ojinnaka, M.C., Ojimelukwe, P.C., Ezeama, C.F. (2013). Microbial and enzymatic changes associated with the production of ogiri from castor oil bean using B. subtilis as starter culture. Sky Journal of Food Science, $2(2), 10-18$

Olanbiwoninu, A.A., Odunfa, S.A. (2018). Microbial interaction in selected fermented vegetable condiments in Nigeria. International Food Research Journal, 25(1), 439 - 455.

Olasupo, N.A., Okorie, P.C. (2019). African fermented food condiments: Microbiology impacts on their nutritional values In: Frontiers and new trends in the science of fermented food and beverages. Intech Open, 120.

Peter-Ikechukwu, A.I., Ijeoma, O., Charles, O.C., Euphresia, N.O., Anthonia, U. E., Chioma, E. (2015). Effect of wrapping material on chemical and microbiological qualities of fermented melon seed (Citrullus vulgaris $\mathrm{L}$. Series). Analytical Chemistry, 15(2), 74-82.

Peter-Ikechukwu, A.I., Kabuo, N.O., Alagboso, S.O., Njoku, N.E., Eluchie, C.N., Momoh, W.O. (2016). Effect of wrapping materials on physicchemical and microbiological qualities of fermented melon seed (Citrullus colocynthis L.) used as ondiment. American Journal of Food Science and Technology, 4(1), 14-19.

Sanni, A.I., Ayenor, G.S., Sakyi-Dawson, E., Sefa-Dedeh, S. (2000). Aerobic spore forming bacteria and chemical composition of some Nigerian fermented soup condiments. Plant Foods for Human Nutrition, 55, 111118

Smith, A.C., Hussey, M.A. (2016). Gram Stain Protocols. American Society for Microbiology, 1-9.

Umar, M., Mohammed, I.B., Abdulkarim, I.M., Yusuf, G., Yaya, A.A., Leo, G. (2016). Comparative studies on the prevalence of Salmonella species in two homemade fermented beverages (zobo and kunu-zaki) sold at Samaru, Zaria, Kaduna, Nigeria. International Journal of Scientific and Research Publications, 6(3), 428-435.

Watanabe T. (2010). Pictorial Atlas of Soil and Seed Fungi: Morphologies of Cultured Fungi and Key Species $3^{\text {rd }}$ ed. Boca Raton; CRC Press. 